\title{
Blended Bibliocounseling
}

\author{
Blasius Boli Lasan \\ Department of Guidance and Counseling \\ State University of Malang, Indonesia \\ blasiusbolilasan@yahoo.co.id
}

\begin{abstract}
Blended bibliocounseling is a new discourse in the world of guidance and counseling compared to blended learning discourse. Bibliocounseling implementation so far can be said to be monotonous because it is only based on reading material from a book. Now, bibliocounseling can be mixed from both the type and source of the material and the delivery method. Bibliocounseling material sources are taken from books, magazines, newspapers, journals, online web, cinema, songs, and poems. Delivery methods can be done by reading books, expressive writing, watching educational cinema, reading poetry, playing roles, even singing. This paper will discuss learning in the $21^{\text {st }}$ century and the stages of developing blended counseling: analysis, design and evaluation.
\end{abstract}

Keywords: blended bibliocounseling, $21^{\text {st }}$ century

\section{INTRODUCTION}

What is the fastest changing world? Many factors certainly. But one of the most important is engineering including information technology. Information technology has caused the information to be collected on a large scale and can be accessed anytime and anywhere, not in schools or libraries. Thousands of books in multilevel libraries can be summarized in several flash disks.

Therefore information technology has formed learning networks, universal intelligence, and democracy in education and science. Scholarship in the sense that a number of scientific information has been obtained in one area may have become a mere formality because other people are diligent in accessing information in a field and training themselves even more than a scholar who only reads a few books.

\section{BIBLIOCOUNSELING IN THE $21^{\text {st }}$ CENTURY}

The sophistication of information technology not only accesses the amount of information but forms a new way of learning in the $21^{\text {st }}$ century which also influences the implementation of bibliocounseling. Trilling and Fadel (2009) mention 4 characteristics of 21 st century learning are knowledge work, thinking tools, digital life styles, and learning research. Knowledge work (works based on knowledge) is a teacher or counselor who has been trained to rely on the power of thought and digital tools. They work collaboratively or on a team using cell phones, internet protocol communication, teleconferencing, WEB conferences, laptops, personal digital assistance and social networking media. Thinking tools are digital tools that can help a person to learn, think, and be creative.

Digital life styles are a pattern of life that utilizes many digital tools in life because their lives have been surrounded by digital devices since childhood. These users are called digital natives, net geners, $\mathrm{Z}$ generations, netizens, homo zapiens. Learning research that involves authentic learning, namely learning to experience directly in a context, developing a mental model that is changing the old mental model with a new mental model, internal motivation that is motivating oneself to learn, double intelligence that is utilizing plural intelligence for learn various things, and social learning namely learning from others, learning to develop social skills and crosscultural skills.

According to Joice and Calhoun (2012), there were three major changes due to the influence of information technology. First is a new library. With the existence of information technology, a large number of books are available which can be accessed for 24 hours. This means that clients can read any book according to their needs, anytime and anywhere. Libraries throughout the world will be connected to each other through information technology so that it is no longer referred to as a particular college library but is called a world library. That's where there are websites, Wikipedia articles, maps, scientific studies and theories. And there also bibliocon counseling can use it as a source of material and delivery methods. Our cellphones can record information using sophisticated cyber assistance. Therefore many conventional libraries and museums are connected to one in the new electronic home.

Second, distance learning. With the existence of information technology that can provide massive information and online courses, anyone can learn something without having to enter a school building. Therefore online homeschooling can be found everywhere. Statistics show that 3\% of American children now study at home or attend homeschooling. This means that bibliocounseling only by reading books without having to meet with counselors can be easily implemented.

Third, new courses. With the existence of cyberspace in schools, the opportunity to learn something outside the material the curriculum is wide open. Likewise counselors and teachers can also provide courses through structured learning materials. In the course, counselors direct their students through activities designed to shape certain types of knowledge and skills so that they form the new behaviors they expect. 


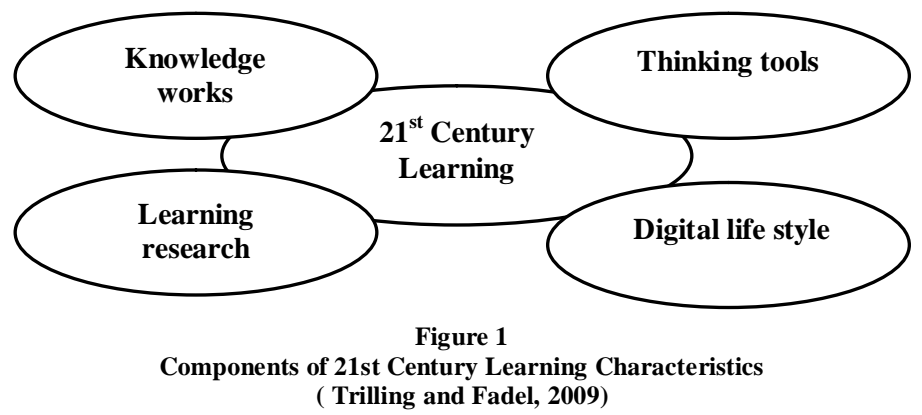

Bibliocounseling certainly also utilizes the influence of information technology. In the past, bibliocounseling was to hear stories from books read developing into each participant reading a book, hearing explanations about the contents of the book both verbally and with power points, audio visual in educational cinema, reading books and being confirmed to a web, even the material could be packaged in a mobile form so that it can be carried everywhere. So blended bibliocounseling now includes books, film shows, concept visualizations, electronic information, web use and not only by reading but listening, seeing, demonstrating, telling, and playing drama, reading poetry, writing, and singing.

In addition, the delivery method can be done by: a. read selected prose, such as novels, autobiographies, and self-help books, b. reading poetry works, such as classical or modern poetry, c. write journals or write autobiographies in whatever form they want such as telegraphic, poetry, reflective thinking, and description of events, d. pay attention to the way the client literature by expressing himself in counseling such as using selected metaphors, and developing new ones, e. write memory books that include ceritra narratives, anecdotes, poems as well as songs, photography and genograms (Glading, 2011; Pennebaker, 2016; Adams, 2014). This is what is called blended or hybrid bibliocounseling.

\section{STAGES OF BIBLIOCOUNSELING DEVELOPING}

Basically, blended bibliocounseling stages is the same as blended biblioconstruction blended learning even though it has different nuances. Therefore, the development of blended bibliography counseling follows the stages of blended learning development by Dwiyogo (2016) abstracted in the following model (Figure 2). In this model, there are 3 main stages namely the analysis stage, the design stage, and the evaluation stage. However, in this paper, adjustments are made in accordance with the nature and procedures of bibliocounseling.

\section{Analysis Phase}

There are three activities carried out in the analysis phase, namely the analysis of problem solving needs, analysis of learning resources and constraints, identification of the characteristics of the counselee.

\section{Problem Solving Needs Analysis}

Of course, the counselor first needs to know the problems faced in doing bibliocon counseling and therefore need to solve problems. The problem experienced in face-to-face counseling is the limited information in bibliocounseling material. For example, the book used has been published for a long time so that information or language is difficult to understand. Therefore problem solving is planning a blended bibliocounseling. Second, identify the competencies that counselors need to have so they can run blended counseling properly. He should have certain knowledge, skills and attitudes related to blended counseling, for example he needs to know what equipment (equipment) needs to be prepared, how to operate it, and how he should behave. Even a new problem needs to be anticipated, such as whether all students can operate the web smoothly.

Based on the needs analysis, the books needed, for example, which discuss: (1) prevention and control of dangerous diseases in behavior; (2) personal mental health and welfare; and (3) services related to social and emotional intelligence, d. Problems related to lack of skills that have an impact on the development of developing skills that have an impact on healthy behavior. Likewise the provision of books related to basic services: biblioedukasi about literacy awareness in the era of information technology, components of individual planning programs: knowing and developing themselves, responsive components: healthy living without cigarettes and drugs (on consumer counselees), individual planning components: how to develop digital library and so on (Antila, 2009).

\section{Learning Source Analysis and Constraints}

Based on the problems that have been identified such as limited bibliocounseling sources, it is necessary to analyze learning resources. If the web as a source of learning, it is necessary to analyze web names that can be used for certain types of problems. Then it is necessary to analyze the aspects that exist in the web, the scope of the material coverage, the quality of the material in the sense that it can be trusted, the ease of the language used. In addition, the obstacles that need to be analyzed are the easy access to the web, the use of language such as foreign languages or Indonesian, and whether the writing is systematic or not. 


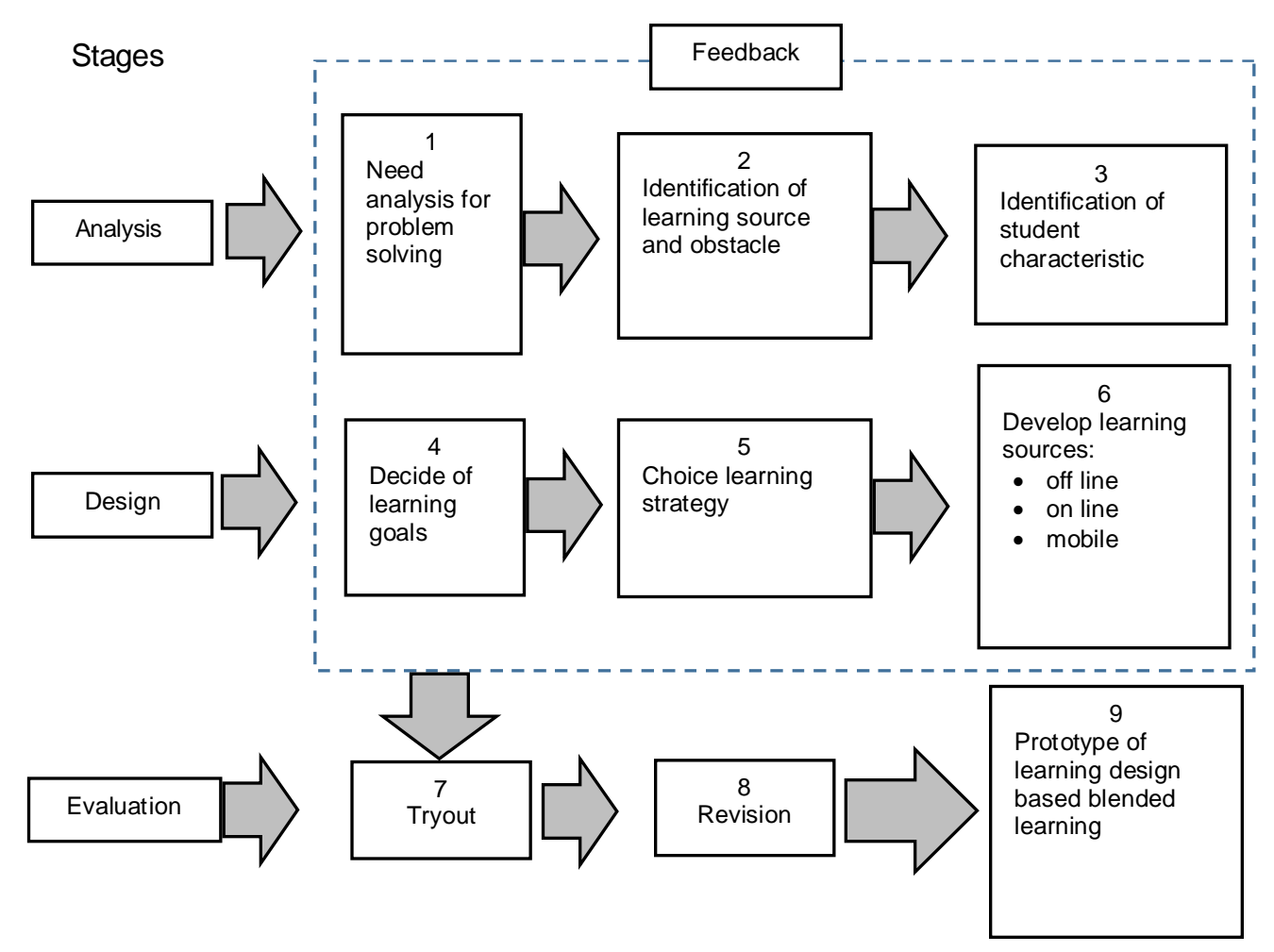

Figure 2

The Bibliocounseling Blended Design Model

(Dwiyogo, 2016)

Thus the bibliocounseling becomes blended because .... used of written materials or computer programs, or the listening / viewing of audio / videotapes for the purpose of gaining understanding problems relevant to developmental or therapeutic needs (Marrs, 1995; Apodaca and Miller, 2003). Blending is located in computer programs, listening / seeing audio / videotypes that previously were only based on reading material. Likewise, Shechtman (2009) emphasized that bibliotherapy entails the use of literature for therapeutic purposes and it includes listening to stories and poems, watching films, and looking at pictures. It is a playful, engaging, and fun process.

\section{Identify the Characteristics of the Counselee}

In general, it is necessary to know whether this bibliocounseling is for elementary, middle, high school, vocational high school students or other types and levels of school. In addition to these general characteristics, it is necessary to identify the counselee's reading ability. If elementary and junior high school students, it is necessary to prepare a web whose contents are easily understood. Another feature that needs to be considered is interest in reading. If the counselee is interested in a material, he will be happy to enjoy the reading.

\section{Design of the Bibliocounseling}

In the bibliocounseling plan by following the Wiyogo mentioned above, there are three things that need to be designed as follows.

\section{Establish Bibliocounseling Goals}

The purpose here is not the general bibliocounseling purpose but the purpose of designing a blended bibliocounseling. The goals are: (1) counselees can confirm their understanding with other sources; (2) counselees broaden their horizons about solving a problem from other sources; and (3) counselees are not bored with the source of the book. While the curricular objectives of the counselee certainly can understand, analyze, appreciate the content of good reading contained in the material off line and on line.

\section{Choose and Establish a Bibliocounseling Strategy}

Blended bibliocounseling is a mixture of methods, stages and learning resources. This is in line with the opinion of Bower, Richard and Lovell (in Rickwood and Bradford, 2012) that bibliocounseling is a therapeutic intervention that is packaged through manuscripts, audio, video, or computer scripts, or through group meetings or personal training such as therapeutic writing and especially designed to be carried out independently of professional contact.

Likewise according to Forgan (2012), that before bringing a ceritra (prabaca stage), it's good to be given an introduction as a background (Forgan, 2002) such as showing pictures on a cover and asking students to guess what happened in ceritra, introducing characters in in the book and discuss student experiences related to the character. Therefore, a blended bibliocounseling strategy can be developed aspects: the biliary counseling stage, the delivery 
method and the source of the material as in the following Table 1 .

\section{Develop Bibliocounseling Resources}

Learning resources are things that are used as learning media. Learning resources can come from people (man of resource), environment (environment of resource), printed materials such as books, magazines, newspaper articles, documents, electronic books, articles in the web, films or cinema and etc. Dwiyogo (2016) distinguishes learning resources in blended learning there are two, namely offline and online.

Furthermore Dwiyogo (2016) mentions 4 stages of developing learning resources: (1) the storyboarding stage which describes the process of presenting the material to clarify the program to be produced; (2) the production stage which is to prepare successfully every component of the program so that it becomes one program as one unity; (3) testing and review phases: (a) editorial review that is checking word writing errors, (b) technical tests to check the functioning of technical matters in program implementation, (c) technical review to ensure that the technical matters that have been repaired have functioned properly or not; and (4) the implementation phase namely the application of the media in bibliocounseling.

Table 1

A Blended Bibliocounseling Strategy

\begin{tabular}{|c|c|c|c|}
\hline Biblio-counseling Stages & Activity & Method & Source \\
\hline Pre-reading & $\begin{array}{l}\text { 1. Select books or other reading } \\
\text { material, choose the web, } \\
\text { cinema that fits the counselee's } \\
\text { problems }\end{array}$ & Select book, web, cinema & $\begin{array}{l}\text { Books, reading materials available } \\
\text { in bibliocounseling, web and } \\
\text { cinema rooms related to counselee } \\
\text { issues }\end{array}$ \\
\hline Guided Reading & $\begin{array}{l}\text { 2. Inviting counse-lees to read } \\
\text { what parts and what needs to } \\
\text { be done when and after reading }\end{array}$ & Guide student & $\begin{array}{l}\text { Guidebook and or explanation of } \\
\text { how to read material }\end{array}$ \\
\hline Reading (Offline) & 3. Reading & $\begin{array}{l}\text { - Silent reading } \\
\text { - Reading aloud } \\
\text { - Reading alternately } \\
\text { - Reading by scaning }\end{array}$ & $\begin{array}{l}\text { Offline: books or reading } \\
\text { materials }\end{array}$ \\
\hline \multirow[t]{2}{*}{ Explanation } & 4. Discussing material content & $\begin{array}{l}\text { - Explanation by power point } \\
\text { - Story Telling }\end{array}$ & $\begin{array}{l}\text { Power point (If reading material } \\
\text { from story book, novel, biography }\end{array}$ \\
\hline & 5. Scafolding (if need) & $\begin{array}{l}\text { - Remedial to counselee who not } \\
\text { yet understand }\end{array}$ & idem \\
\hline \multirow[t]{3}{*}{ Connect to web (On line) } & 6. Reading the content & - Idem to number 3 above & Connect Online to web situs \\
\hline & $\begin{array}{l}\text { 7. Discussing the content of } \\
\text { materials }\end{array}$ & $\begin{array}{l}\text { - Explanation } \\
\text { - Mind mapping of materials }\end{array}$ & $\begin{array}{l}\text { Counselor } \\
\text { Mind mapping of materials }\end{array}$ \\
\hline & 8. Scafolding (if need) & - Explanation & Idem \\
\hline Discussion & $\begin{array}{l}\text { 9. Discussions about the content } \\
\text { of reading both offline and } \\
\text { online, by giving the counselee } \\
\text { an opportunity: }\end{array}$ & $\begin{array}{l}\text { Explore events in the story / } \\
\text { reading so that there is a } \\
\text { transfer of feelings to the } \\
\text { counselee } \\
\text { - Identify the same situation in } \\
\text { his real life } \\
\text { - Explore the consequences of } \\
\text { certain actions or feelings } \\
\text { - Determine the desire/plan of } \\
\text { action after this. }\end{array}$ & Offline and online \\
\hline Watch cinema & 10. Audio-visual & $\begin{array}{l}\text { - Listen } \\
\text { - Involved } \\
\text { - Received } \\
\end{array}$ & Educational cinema \\
\hline Writing & $\begin{array}{l}\text { 11. Writing Absraction } \\
\text { 12. Writing poem/song }\end{array}$ & $\begin{array}{l}\text { Writing Absraction } \\
\text { Writing poem }\end{array}$ & Bibliocounseling materials \\
\hline Sing a song (if need) & $\begin{array}{l}\text { 13. Sing a song that well known or } \\
\text { the song that created by your } \\
\text { self }\end{array}$ & Sing a song by guitar or acapela & Song \\
\hline Conclusion (if need) & $\begin{array}{l}\text { 14. Counselee conclude the } \\
\text { content of materials }\end{array}$ & $\begin{array}{l}\text { Conclusion } \\
\text { Think aloud }\end{array}$ & $\begin{array}{ll}--- \\
--- \\
\end{array}$ \\
\hline Reflextion & $\begin{array}{l}\text { 15. Pick the meaning for to } \\
\text { develop his or her self }\end{array}$ & Pick the meaning & --- \\
\hline CommitmenTreatment & $\begin{array}{l}\text { 16. Open the mobile material from } \\
\text { handphone, sing the song for } \\
\text { develop his or her self }\end{array}$ & $\begin{array}{l}\text { Open the hand phone } \\
\text { Sing }\end{array}$ & $\begin{array}{l}\text { Ponsel } \\
\text { Guitar }\end{array}$ \\
\hline
\end{tabular}

\section{Evaluation Phase}

Evaluation begins with product trials in the form of a bibliocounseling design that has been produced in the previous step. If there are deficiencies in the trial, the bibliocounseling product will be revised to obtain a blended bibliocounseling prototype. The details of these three things are as follows.

\section{Try Out}

The trial means that the bibliocounseling blended product is applied as an experiment against the counselee both individually and in groups. Trials should be given several times to a number of groups so that conclusions about their effectiveness are more 
trusted, not only limited to a counselee or a group of students. These products should be tried in several schools that are spread over several characteristics: schools in big cities, schools in rural areas, favorite schools and traditional schools, and several other features.

\section{Revision}

The trial results show the advantages and disadvantages of a blended bibliocounseling product. These strengths are maintained or enhanced but their weaknesses are revised. If counselees find it difficult to understand the offline material, the counselor needs to rewrite the material in a language that is easily understood and accompanied by examples. It could also be that the material contains foreign concepts that are difficult to understand, so the term should be replaced or added with information in Indonesian. Scafolding can also be needed to understand the material. Likewise, online material does not all match the needs of the counselee's problem solving. The material can also be shared, but the counselor fails to make an explanation, fails to bring students to identification, fails in speech, and fails to transfer behavior. So all these deficiencies require revision.

\section{Bibliocounseling Blended Products}

Arrived at the end of the blended bibliocounseling prototype that has gone through various stages. But this prototype is not a product that is always good when and wherever and by anyone. No! This prototype is a kind of general guideline that needs to be adjusted to the type of problem, the type of client, and where the place is carried out by a blended bibliocounseling. If at one time and in a place requires adjustments and even changes, the counselor needs to follow back from the beginning to the end, namely analysis, design and evaluation.

\section{CONCLUSION}

The conclusion that can be drawn is as follows. First, there are 4 characteristics of learning in the 21 st century that can be used by bibliocounseling: knowledge work, thinking tools, digital life styles, and learning research. Both bibliokoseling can utilize information technology as a source of material and as a delivery method.

The three blended bibliocounseling developments include 3 stages: analysis, design, and evaluation. At the analysis stage identified the needs of students to get services from bibliocounseling. At the design stage: set goals, choose and design bibliocounseling, develop bibliocounseling resources. During the evaluation phase, the trial, revision, and final product are held.

\section{REFERENCES}

[1] Adams, K. E. 2014. Expressive Writing: Classroom and Comunity. Lanham: Brown \& Littlefield.

[2] Antila, R. D. 2009. Bibliotherapy and the K-5 Michigan Model for the Health Curriculum. Thesis not published. Michigan: Northern Michigan University.
[3] Apodaca, T. R., \& Miller, W. R. 2003. A Meta-Analisis of the Effectiveness of Bibliotherapy for Alcoholic Problems. Journal of Clinical Psychology, 59(3), 289-304.

[4] Dwiyogo, D. W. 2016. Blended Learning. Malang: Wineka.

[5] Forgan, J. W. 2002. Using Bibliotherapy to Teach Problem Solving. Journal of Intervention in Schools and Clinic, 38(2), 75-82.

[6] Gladding, S. T. 2011. The Creative Arts in Counseling. New York: American Counseling Association.

[7] Joyce, B., \& Calhoun, E. 2012. Realizing the Promise of $21^{\text {st }}$ Century Education. United States Of America. Library of Congres Cataloging.

[8] Marrs, R. W. 1995. A Meta-Analysis of Bibliotherapy Studies. American Journal of Community Psychology, 23(6).

[9] Pennebaker, J. W., \& Smith, J. M. 2016. Opening Up by Writing it Down How Expressive Writing Improves Health and Eases Emotional Pain. New York: Guildford Press.

[10] Rickwood, D., \& Bradford, S. 2012. The Role of Self-Help in the Treatment of Mild Anxiety Disorders in Young People: An Evidence-Based Review. Psychology Research and Behavior Management, 5, 25-36.

[11] Shechtman, Z. 2009. Treating Child and Adolescent Agression Through Bibliotherapy. New York: Springer.

[12] Trilling, B., \& Fadel, C. 2009. $21^{\text {st }}$ Century Skills Learning for Life in Our Times. San Fransisco: Jossey-Bass. 